\title{
セラミックスの疲労寿命の多重モードワイブル分布による解析
}

\author{
松尾陽太郎 - 大井田俊彦 - 神 保勝 久* · 安田公一 - 木 村 脩 七 \\ ( 東京工業大学工学部無機材料工学科, 152 東京都目黒区大岡山 2-12-1 ) \\ * 東京工業大学工学部生産機械工学科, 152 東京都目黒区大岡山 2-12-1)
}

\section{Analysis of Fatigue Life of Ceramics Using Multi-Modal Weibull Distribution}

\author{
Yohtaro MATSUO, Toshihiko OIDA, Katsuhisa JINBO*, Kouichi YASUDA and Shiushichi KIMURA \\ Department of Inorganic Materials, Faculty of Engineering, Tokyo Institute of Technology, \\ 2-12-1, O-okayama, Meguro-ku, Tokyo 152 \\ * Department of Mechanical Engineering for Production, Faculty of Engineering, Tokyo Institute of Technology, \\ 2-12-1, O-okayama, Meguro-ku, Tokyo 152
}

\begin{abstract}
A new theory was formulated for analyzing the cyclic fatigue behavior of ceramics by combining the multi-modal Weibull distribution function with slow crack growth law $\left(S . C . G_{\text {. }}\right.$ ). Using an internal pressure testing machine, static and fatigue tests were performed on cylindrical alumina specimens. Statistical data analysis showed that cyclic stress reduces the number of cycles to failure. Intergranular fracture was dominant on fatigue fractured surfaces. The semi-length of the crack at branching has been best correlated with the peak applied stress in the cyclic fatigue test. The least of the number of cycles to failure was ensured for the specimens passing through the pre-loading proof test.
\end{abstract}

[Received August 15, 1988; Accepted October 21, 1988]

Key-words : Cyclic fatigue, Multi-modal Weibull distribution, S. C. G., Alumina, Internal pressure, Crack branching, Proof test

\section{1. 緒言}

セラミックスを構造材料として使用するためには，そ の強度, 破壊䩲性についての知見とともに, 疲労特性に ついての十分なデータの集積が必要である。 セラミック スの繰り返し疲労に関する研究は既にかなりの数の報告 がなされているが, その多くは曲げ, 引張, 回転曲げな どの実験結果である. また, 大量デー夕が報告された例 も少ない。

一方, セラミックス製円筒は, 耐熱管, 炉心管等とし て広く利用されているが, 反応管や海水ポンプなどの部 材として高圧で長期間使用するような場合の疲労挙動に ついての実験はまだほとんどなされていない。

著者らは先に, Evans ら', Wiederhorn' ${ }^{2)}$, Ritter $ら^{3), 4)}$ の理論を拡張して, セラミックスの不均一応力場 における不活性強度に関する多重モードワイブル分布と 低速き裂進展則を結合したいくつかの新しい理論式を提 唱し,これらが保証試験の解析 ${ }^{5)}$, 静疲労試験における 破損寿命の予測 ${ }^{5)}$, 定負荷速度試験における破壊応力の 予測 ${ }^{5), 6)}$ に有効であることを示した。

本論文では，これらの理論を繰り返し疲労問題に拡張 するとともに, アルミナ円筒の内圧疲労試験の実験結果 への適用を試みた。 実験で得られた大量の疲労寿命デー 夕の統計解析を行い, 繰り返し疲労寿命分布に及ぼす応 力の変動の効果について考察した. また, 疲労破壊した
試験片のフラクトグラフィーより, 破壊様式に関して検 討した. 更に, 保証試験を通過した試験片に対しても繰 り返し内圧疲労試験を試み, 保証試験の有効性について 調べた。

\section{2. 繰り返し疲労寿命分布の解析}

セラミックスの繰り返し疲労におけるき裂の進展の主 なものは, (1)低速き裂成長, (2)応力の変動による(1)以外 のき裂進展, の二つが考えられる. (1)については古くか ら多くの研究がなされ, き裂進展則もほぼ確立されてい る.しかし, (2)のき裂進展メカニズムについては, Ewart $ら^{7), 8)}$ により圧縮応力の効果が検討されている程 度でまだほとんど不明と言ってよい, そのため, 以下で は, (1)のS.C.G.によるき裂進展のみを考慮した解析 を行う。

解析に当たって以下のように仮定をする。（1）即時 破壊強度と疲労寿命は 1 対 1 に対応し, 破壊源となるき 裂の強度の順序は両者で一致する。(2) 不活性強度分 布は多重モードワイブル分布で記述される。( 3 ) 疲労 き裂の進展はS.C.G.のみに支配される.このとき， 疲労き裂の進展は $K_{\mathrm{I}}-V$ ダイアグラム ${ }^{9)}$ における第 $\mathrm{I}$ 領 域が律速になっており, そのき裂進展速度は, $\mathrm{d} a / \mathrm{d} t=$ $A K_{\mathrm{I}}^{n}$ で表される. ここで， $K_{\mathrm{I}}-V$ ダイアグラムの第 I 領 域が直線で近似できる ${ }^{10)}$ と仮定すると, $n$ は一定値と 
なる.（4）き裂の相互干渉はない.

\section{1 均一応力場における解析}

応力拡大係数およびき裂進展則として（1）式，（2） 式を採用する。

$$
\begin{aligned}
& K_{\mathrm{I}}=Y \sigma(t) \sqrt{a} \\
& \frac{\mathrm{d} a}{\mathrm{~d} t}=A K_{\mathrm{I}}^{n}
\end{aligned}
$$

ここで， $\sigma(t)$ は時刻 $t$ における応力， $a$ はき裂の代表 寸法, $Y$ は形状係数, $A, n$ はき裂進展パラメーターで ある・

応力の周期的な時間変化が,

$$
\sigma(t)=\sigma_{\max } \cdot h(\omega t) ; \omega: \text { 角速度 }
$$

で表されるとすると, 疲労破壊までの繰り返し数 (寿命) $N$ は不活性強度 $\sigma_{i}$ の関数として次式のように表され る11).

$$
\begin{aligned}
& N=\frac{B}{\sigma_{\max }^{n} \int_{0}^{2 \pi / \omega} h(\omega t)^{n} \mathrm{~d} t} \sigma_{i}^{n-2} \\
& B=\frac{2}{(n-2) A Y^{2} K_{\mathrm{IC}}^{n-2}}
\end{aligned}
$$

ここで， $K_{\mathrm{IC}}$ は破壊䩲性値である。

不活性強度 $\sigma_{i}$ の分布としては, 次式で表される多重 モードワイブル分布 ${ }^{12) ~ 14)}$ を仮定する。

$$
F\left(\sigma_{i}\right)=1-\exp \left\{-\sum_{h=1}^{k} B_{\mathrm{h}}\right\} ; B_{\mathrm{h}} \text { : 破壊の危険率 }
$$

ここで, 添字 h は破壊源となる欠陥の種類を， $k$ は考慮 すべき欠陥の種類の総数を表す。位置母数 ${ }^{15)}$ を 0 と仮 定すると, 破壊源 h $の$ みが存在するとしたときの，不 活性強度 $\sigma_{i}$ に関する確率分布関数 $F_{\mathrm{h}}\left(\sigma_{i}\right)$ は,

$$
F_{\mathrm{h}}\left(\sigma_{i}\right)=1-\exp \left\{-A_{0 \mathrm{~h}}\left(\frac{\sigma_{i}}{\sigma_{0 \mathrm{~h}}}\right)^{m_{\mathrm{n}}}\right\}
$$

となる。ここで $A_{0 \mathrm{~h}}$ は無次元の有効表面積 (又は体積)， $m_{\mathrm{h}}$ と $\sigma_{0 \mathrm{~h}}$ はそれぞれ，形状母数及び尺度母数である。

(4) 式亡（7）式から繰り返し疲労寿命分布を求め てみる。（4）式を用いて（7）式の変数を $\sigma_{i}$ から $N$ に変換すると, 繰り返し疲労寿命 $N$ の確率分布関数 $F_{\mathrm{h}}$ $(N)$ として次式を得る.

$$
F_{\mathrm{h}}(N)=1-\exp \left\{-A_{0 \mathrm{~h}}\left(\frac{N}{N_{0 \mathrm{~h}}}\right)^{m_{\mathrm{Nh}}}\right\}
$$

ここで， $m_{\mathrm{Nh}}$ 及び $N_{\mathrm{oh}}$ はそれぞれ疲労寿命分布におけ る形状母数及び尺度母数で，以下の式で表される。

$$
\begin{aligned}
& m_{\mathrm{Nh}}=\frac{1}{n-2} m_{\mathrm{h}} \\
& N_{\mathrm{oh}}=\frac{B}{\sigma_{\max }^{n} \int_{0}^{2 \pi / \omega} h(\omega t)^{n} \mathrm{~d} t} \sigma_{0 \mathrm{~h}}^{n-2}
\end{aligned}
$$

$k$ 種類の欠陥が低速き裂成長し，その“競合”の結果 として疲労破壊が起こるとすると, 疲労寿命 $N$ の確率 分布関数 $F(N)$ は次式のように定式化される.

$$
F(N)=1-\exp \left\{-\sum_{h=1}^{k} A_{0 \mathrm{~h}}\left(\frac{N}{N_{0 \mathrm{~h}}}\right)^{m_{\mathrm{Nh}}}\right\}
$$

上式は (6) 式の不活性強度分布と同様に繰り返し疲 労寿命分布が多重モードワイブル分布に従うことを意味 している。

\section{2 不均一応力場における解析}

前節で述べた解析結果をもとにして, 不均一応力場に おける解析を行う。

物体の表面や内部の各点に作用する最大主応力 $\sigma_{1}(\boldsymbol{r})$ が, 座標 $\boldsymbol{r}$ の無次元関数 $g(\boldsymbol{r})$ と, 応力の次元を持つ 代表值 $\sigma_{\text {rep }}$ とにより

$$
\sigma_{1}(\boldsymbol{r})=\sigma_{\mathrm{rep}} \cdot g(\boldsymbol{r})
$$

の関係で表されるとする，ここで， $\sigma_{\text {rep }}$ として，

$$
\sigma_{\mathrm{rep}}=\sigma_{\max } \cdot h(\omega t)
$$

で表される周期的な応力を考え，物体の表面（内部）を $n$ 個の微小な面積要素 (体積要素) $\Delta A_{j}$ に分割したとき, 任意の要素内の最も危険なき裂の疲労寿命は次式,

$$
N_{j}=\frac{B}{\left\{\sigma_{\max } g\left(\boldsymbol{r}_{j}\right)\right\}^{n} \int_{0}^{2 \pi / \omega} h(\omega t)^{n} \mathrm{~d} t}\left(\sigma_{i}\right)_{j}^{n-2}
$$

で表される。また， $\Delta A_{j}$ 内に破壊源 $h$ のみが存在する と仮定したときの，不活性強度 $\sigma_{i}$ の確率分布関数 $F_{\mathrm{h}}$ $\left[\left(\sigma_{i}\right)_{j}\right]$ は, 2 母数ワイブル分布,

$$
F_{\mathrm{h}}\left[\left(\sigma_{i}\right)_{j}\right]=1-\exp \left\{-\Delta A_{j}\left(\frac{\left(\sigma_{i}\right)_{j}}{\sigma_{0 \mathrm{~h}}}\right)^{m_{\mathrm{h}}}\right\}
$$

で与えられるものとする。（8）式と同様にして，(14) 式, (15) 式にて, $\left(\sigma_{i}\right)_{j}$ から $N_{j}$ への変数変換を行い, $k$ 種類の欠陥が低速き裂成長すると仮定すると, 物体全 体の疲労寿命の代表值 $N_{\mathrm{rep}}$ の分布は, 破壊の危険率を 全要素について足し合わせ， $\Delta A_{j} \rightarrow 0$ の極限をとること により，次式のように表される.

$$
\begin{aligned}
& F\left(N_{\text {rep }}\right)=1-\exp \left\{-\sum_{h=1}^{k}\left(A_{\text {eff }}\right)_{\mathrm{h}}\left(\frac{N_{\text {rep }}}{N_{\text {oh }}}\right)^{m_{\mathrm{Nh}}}\right\} \\
& \left(A_{\text {eff }}\right)_{\mathrm{h}}=\int_{A_{\mathrm{h}}}\{g(\boldsymbol{r})\}^{n-2} m_{\mathrm{h}} \mathrm{d} A
\end{aligned}
$$

（11）式と比較すると，上式では有効表面積（有効体積） $A_{\text {oh }}$ が新しい有効表面積（有効体積） $\left(A_{\text {eff }}\right)_{\mathrm{h}}$ に置き換 わっている点だけが異なるのみで同形式となっている.

\section{3 円筒形試験片の繰り返し内圧疲労試験の解析}

前節で得られた解析結果を円筒形試験片の繰り返し内 圧疲労試験に適用する。ここで破壊モードは, (1)内面か らの破壊（モード1), (2)外面からの破壊（モード2), (3)内面，外面以外の試料内部からの破壊（モード3）の 3 種類とする. 試験片が内圧のみを受け，軸方向には荷 重を受けないとすると(両端開放条件), 円周方向に引 張応力の働く 1 軸応力状態になる. このとき, 物体の各 点における円周方向応力 $\sigma_{1}(r)$ (引張応力) は,

$$
\sigma_{1}(r)=\sigma_{\text {rep }} \cdot g(r)
$$




$$
\begin{aligned}
& \sigma_{\text {rep }}=\frac{r_{1}}{r_{2}-r_{1}} P \\
& g(r)=\frac{r_{1}}{r_{2}+r_{1}}\left(1+\frac{r_{2}^{2}}{r^{2}}\right)
\end{aligned}
$$

である．ここで， $\sigma_{\mathrm{rep}}$ は円周応力の平均值， $r$ は半径, $r_{1}$ は内径, $r_{2}$ は外径, $P$ は内圧である. 不均一応力場 における解析結果より, 各破壊の危険率は次のように求 まる.

$$
\begin{aligned}
B_{1}= & \left(\frac{N_{\text {rep }}}{N_{01}}\right)^{m_{N_{1}}}\left[2 \pi r_{1} L\left\{\frac{r_{1}}{r_{2}+r_{1}}\left(1+\frac{r_{2}^{2}}{r_{1}^{2}}\right)\right\}^{\frac{n}{n-2} m_{1}}\right] \\
B_{2}= & \left(\frac{N_{\text {rep }}}{N_{02}}\right)^{m_{N_{2}}}\left[2 \pi r_{2} L\left\{\frac{2 r_{1}}{r_{2}+r_{1}}\right\}^{\frac{n}{n-2} m_{2}}\right] \\
B_{3}= & \left(\frac{N_{\text {rep }}}{N_{03}}\right)^{m_{N_{3}}}\left[\int _ { r _ { 1 } } ^ { r _ { 2 } } 2 \pi r L \left\{\frac{r_{1}}{r_{2}+r_{1}}\right.\right. \\
& \left.\left.\left(1+\frac{r_{2}^{2}}{r^{2}}\right)\right\}^{\frac{n}{n-2} m_{3}} \mathrm{~d} r\right]
\end{aligned}
$$

ただし, 後に示すアルミナ円筒の即時破壊及び疲労破壊 試験においては，80％以上の試験片は圧力が直接作用 する内面から破壊していたので，モード 1 のみの単一 モードとして扱い, モード 1 以外のデー夕は打ち切り データとして,最尤法によるパラメーター推定を行った。 また， $10^{7}$ 回非破壊デー夕も，モード 1 以外のデータと 同様，打ち切りデータとして取り扱った ${ }^{16), 17)}$.

\section{3. 実験方法}

\section{1 試験片及び内圧負荷方法}

実験で使用した供試材料は，日本化学陶業製 SSA-S アルミナチューブで, 粉体調整, 成形, 焼成過程等はす べての試料で同一である. その化学組成は, 主成分 $\mathrm{Al}_{2} \mathrm{O}_{3}$ が 99.60 (wt\%), 他に $\mathrm{SiO}_{2}, \mathrm{Fe}_{2} \mathrm{O}_{3}, \mathrm{CaO}, \mathrm{MgO}$, $\mathrm{Na}_{2} \mathrm{O}$ が含まれている. 平均粒径は $12.2 \mu \mathrm{m}$, 見掛け密 度は $3.86 \mathrm{~g} \cdot \mathrm{cm}^{-3}$ である. 試験片は, 供試材より切り出 した, 内径 $11 \mathrm{~mm}$, 外径 $15 \mathrm{~mm}$, 長さ $40 \mathrm{~mm}$ (圧力を 受ける部分は, $24 \mathrm{~mm}$ ) の円筒形状のものである. 内圧 疲労試験装置 ${ }^{17)}$ は閉ループ油圧サーボ式試験装置で, 正弦関数とほぼ等しい内圧を, 圧力媒体を介して最高 8 本までの試験片に負荷することが出来る.圧力媒体には, 圧力の伝達性をよくするため，また，アルミナが圧力媒 体中の水分の変動の影響を受けないようにするために, ベースオイルVG-70（流動パラフィン）を使用した。 圧力媒体のシールにはジョンソン・シール法を採用し, 両端開放内圧条件（軸方向応力が 0 ) とした.

\section{2 即時内圧破壊試験}

供試材料の不活性強度分布を, 負荷速度一定 (9.1 $\left.\mathrm{MPa} \cdot \mathrm{s}^{-1}\right)$ の条件下で測定した。このとき, 破壊強度は, 破壊時の平均円周方向応力から求めた.

次に，負荷速度を広範囲に変化させて即時内圧破壊強
度を調べ，き裂進展パラメーターの推定を行った。 破壊強度 $\sigma_{\mathrm{f}}$ の期待值と負荷速度 $\dot{\sigma}$ の関係 ${ }^{18)}$,

$$
\begin{aligned}
& \ln E[ {\left[\sigma_{\mathrm{f}}\right]=\frac{1}{n+1} \ln \dot{\sigma}+\ln C } \\
& C= \sigma_{01}^{\frac{n-2}{n+1}}[B(n+1)]^{\frac{1}{n+1}} \\
& \quad \times\left[\int_{A} g(\boldsymbol{r})^{\frac{n}{n-2} m_{1}} \mathrm{~d} A\right]^{-\frac{n-2}{(n+1) m_{1}}} \cdot \Gamma\left(1+\frac{n-2}{(n+1) m_{1}}\right)
\end{aligned}
$$

より, $n$ 及び $B$ を推定した.

\section{3 繰り返し内圧疲労試験}

実験は, 片振り正弦関数（応力比 $R=0 \quad(R=$ $\left.\left.\sigma_{\min } / \sigma_{\max }\right)\right)$ の内圧を負荷することによって行った. 平 均最小円周応力 $\sigma_{\min }$ は $0 \mathrm{MPa}$, 平均最大円周応力 $\sigma_{\max }$ は126 MPa, $120 \mathrm{MPa}, 113 \mathrm{MPa}, 107 \mathrm{MPa}, 101 \mathrm{MPa}$, $94 \mathrm{MPa}, 88 \mathrm{MPa}$ の 7 応力レベルとした. 負荷圧力の 精度は土 $1 \%$ であった. 周波数は $15 \mathrm{~Hz}$ ，気温は $20^{\circ}$ $30^{\circ} \mathrm{C}$, 圧力媒体の温度は $30^{\circ} \sim 40^{\circ} \mathrm{C}$ であった。デー夕 数は, 1 応力レベル 16 以上とし, 繰り返し数 $10^{7}$ 回に て破壊しなかった試験片の実験は打ち切った。実験条件 は，即時破壞強度試験のときと同一とした。

\section{4 破面観察}

繰り返し内圧疲労試験により疲労破壊した試験片の破 面観察を肉眼及び走査型電子顕微鏡 $(\mathrm{SEM})$ により行っ た。

種々のセラミックスにおいて破面のミラー半径 $r_{\mathrm{m}}$ と 破壊応力 $\sigma_{\mathrm{f}}$ との間に, $\sigma_{\mathrm{f}} \sqrt{r_{\mathrm{m}}}=$ const. の関係式 ${ }^{19)-21)}$ が, また, き裂の枝分かれまでの距離 $c_{\mathrm{b}}$ と破壊応力 $\sigma_{\mathrm{f}}$ との 間に $\sigma_{\mathrm{f}} \sqrt{c_{\mathrm{b}}}=$ const. の関係式 ${ }^{22), 23)}$ が成り立つことが確 かめられている。疲労破壊においても，これらと類似の 関係があるか否かを調べるために，即時破壊した試験片 及び疲労破壊した試験片について，き裂の枝分かれまで の距離を測定した.

\section{5 保証試験}

保証試験は, 疲労試験を行う前の試験片に対して図 1 に示した波形の荷重を負荷速度，約 $194 \mathrm{MPa} \cdot \mathrm{s}^{-1}$ で与 え，危険な欠陥を持った試験片を破壊し，取り除くこと により行った。保証試験で使用した治具，負荷方法等は 繰り返し内圧疲労試験のときとすべて同一とした．保証

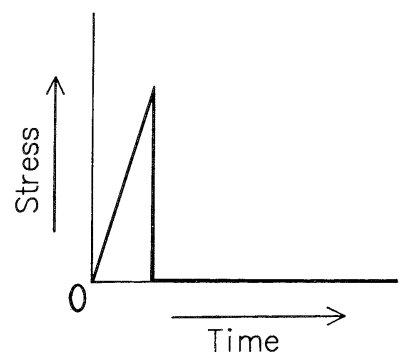

Fig. 1. Loading program in proof testing. 
試験応力は, 平均円周応力で, (1) $156 \mathrm{MPa}$, (2) $163 \mathrm{MPa}$, (3) $166 \mathrm{MPa}$, (4) $170 \mathrm{MPa}$ の 4 応力レベルで武みた. 保 証試験を通過した試験片に対して， $\sigma_{\max }=101 \mathrm{MPa}$ で 3.3 節と同じ条件で繰り返し内圧疲労試験を行い，保証 試験の有効性について調べた。

\section{4. 結果と考察}

\section{1 即時内圧破壊試験}

負荷速度 $9.1 \mathrm{MPa} \cdot \mathrm{s}^{-1}$ におけるモード 1 の不活性強 度データのワイブルプロットを図 2 に示す. 破壊強度が 2 母数ワイブル分布に従うとして, 最尤法により推定し たモード 1 のパラメーターの值は, 形状母数が 16.8 , 尺度母数が $168.5(\mathrm{MPa})$ であった。

即時内圧破壊強度の負荷速度依存性を図 3 に示す。負 荷速度が $10 \mathrm{MPa} \cdot \mathrm{s}^{-1}$ 付近以下のところでは, 破壊強度 は直線的に増加しているが, 負荷速度が $10 \mathrm{MPa} \cdot \mathrm{s}^{-1}$ 付 近以上のところでは, 破壊強度はほぼ一定で不活性強度 とみなせる. 負荷速度が $10 \mathrm{MPa} \cdot \mathrm{s}^{-1}$ 以下のデータより,

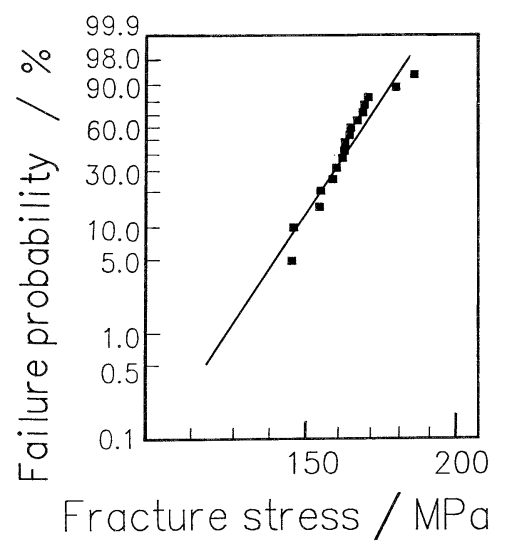

Fig. 2. Weibull plots of fracture stresses of alumina cylinders.
き裂進展パラメーター $n, B$ の值を推定した結果, $n=$ $21, B=16.9 \times 10^{3}\left(\mathrm{MPa}^{2} \cdot \mathrm{s}\right)$ を得た。

\section{2 繰り返し内圧疲労試験}

得られた疲労寿命データを $S-N$ 線図にして図 4 に示 す。応力レベルの低下とともに疲労寿命が徐々に長く なっているが，明瞭な疲労限の存在は認められず， $10^{7}$ 回片振り内圧疲労強度は, 約 $80 \mathrm{MPa}$ 程度である.こ れは, 即時破壊強度の平均值の約 $50 \%$ 程度である。ま た, 各応力レベルにおけるデータのばらつきは $10^{1} \sim 10^{3}$ 回程度と, セラミックスについて報告されている従来の 疲労寿命データに比較して非常に小さい。

モード 1 の疲労寿命データをワイブル・プロットにし たものを図 5 に示す. 図 5 中の直線は, 2 母数ワイブル 分布を仮定したときの回帰直線であり, 実験値とよく一 致している.ワイブルパラメーターと応力レベルの間の 相関性は金属材料において確認されている ${ }^{17)}$ が，図 6 の○印で示したようにセラミックスにおいても両者の間 に強い相関性があることが推察される。すなわち, 応力 レベルに対して, 形状母数は正の相関, 尺度母数（対数

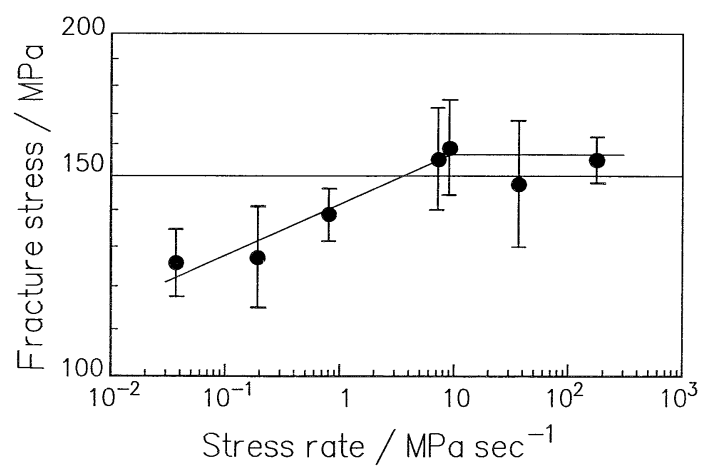

Fig. 3. Stress rate dependence of fracture stress of alumina cylinder.

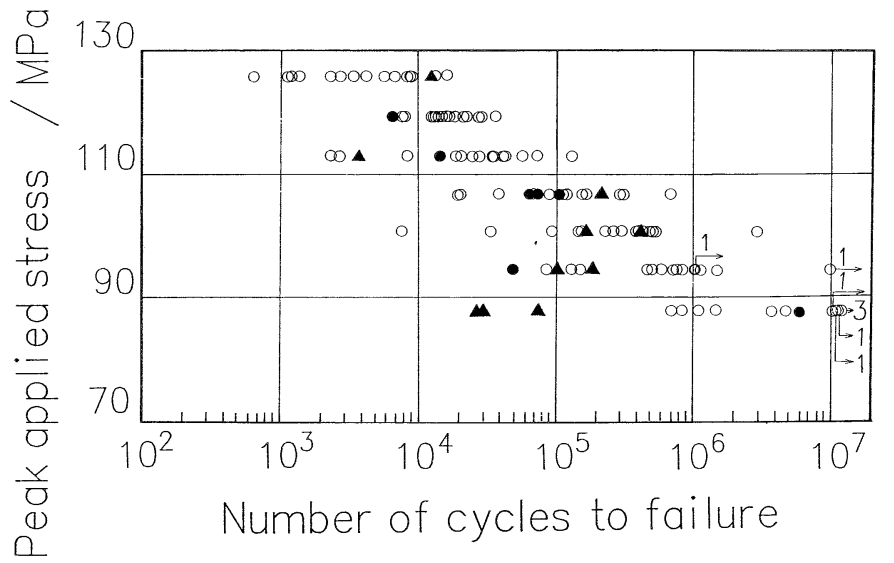

Fig. 4. $S-N$ diagram of alumina cylinder by internal-pressure fatigue testing;

$O$ : failed from inside surface,

: failed from outside surface,

A : fracture origin is unknown. 


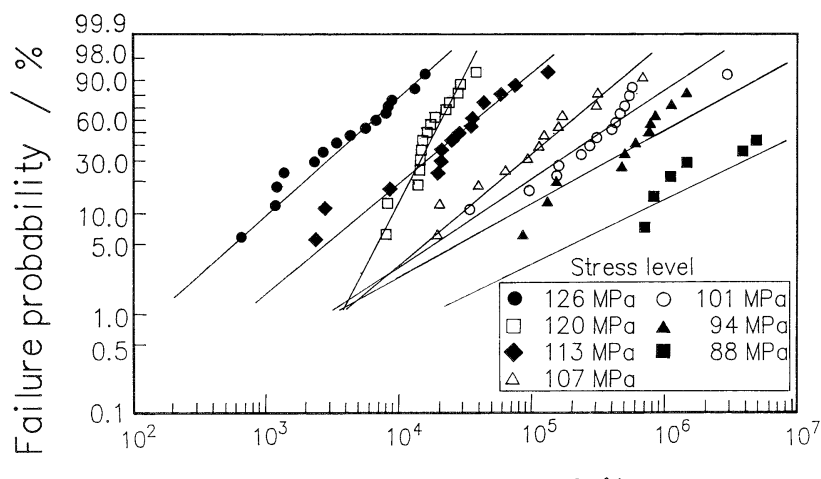

Number of cycles to failure

Fig. 5. Weibull plots of number of cycles to failure of alumina cylinder.

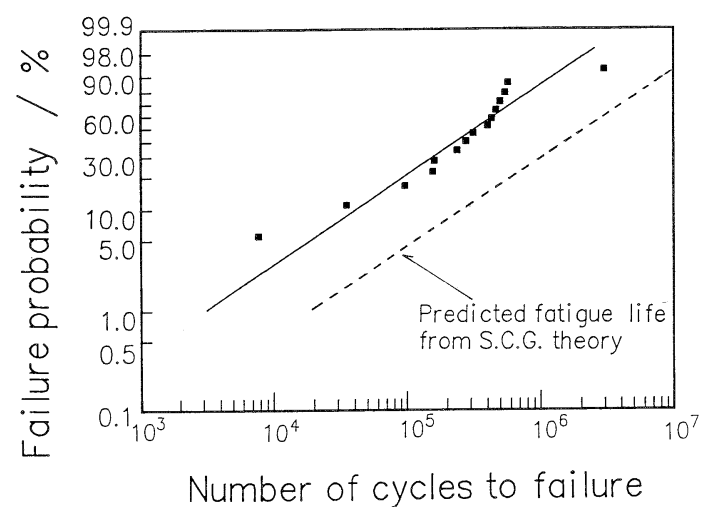

Fig. 7. Predicted fatigue life and the experimental data plotted on Weibull probability paper ( $\sigma_{\max }=$ $101 \mathrm{MPa}$ ).

值）は負の相関がある.

$\sigma_{\max }=101 \mathrm{MPa}$ のとき（8）式から計算した疲労 寿命分布関数の推定曲線と実験データを図 7 に示す。同 図から分かるように推定曲線は，実験值よりも長寿命側 に出ている．他の応力レベルについてもこれと同様の傾 向であった。また，（9）式，(10）式より推定されたワ イブルパラメーターの推定值を図 $6(\mathrm{a}),(\mathrm{b})$ 中の点 線で示す。図 7 での傾向は図 $6(\mathrm{~b})$ で尺度母数の推定 值が実験值よりも高めの値を示していることからも推察 される.また，図 6 ( a ) では, 推定された形状母数の 值は応力值のいかんに関わらず 0.88 と一定となり，実 験値が応力值に対して正の相関がある実験結果と異なっ ている.このことは, S. C. G. 以外の疲労き裂進展入力 ニズムが存在する可能性を示唆している。アルミナの疲 労寿命に及ぼす繰り返し応力の効果については既にいく つかの報告 ${ }^{24) ~ 26)}$ があるが，上述の結果とあわせて今後 更に研究する必要がある.

\section{3 破面観察}

肉眼による破面観察の結果を図 8 に示す。これより破

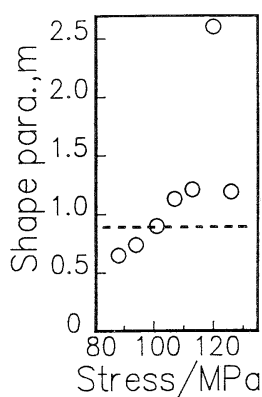

(a)

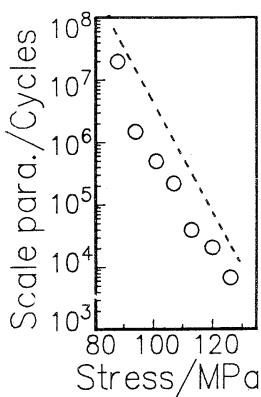

(b)
Fig.6. Stress level dependence of Weibull parameters in internal-pressure fatigue testing of alumina cylinder; dotted lines are predicted results; ( a ) Shape parameter, ( b ) Scale parameter.

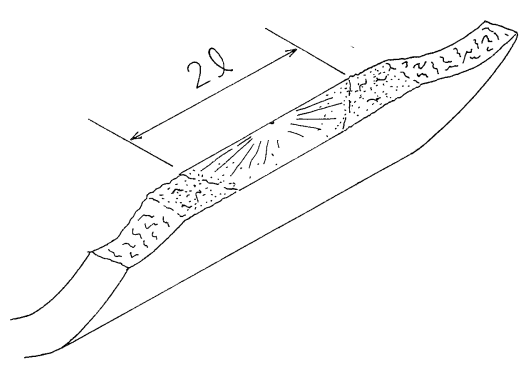

Fig. 8. Illustration of fatigue-fractured surface of alumina cylinder.

壊源の同定を行った結果, 破壊はほとんどモード 1 であ り, モード 2 , モード 3 の破壊は極めて少数だった.

SEM による破面観察を行った結果, 破壊は, 内面の 粗大気孔やスクラッチき裂より起こることが多いことが 分かった. 図 9 は, 内面近くの粗大気孔を破壊源として 破壊が起きている例である。破壊様式は，粒界破壊が支 配的である. しかし, 同図からはどの部分が疲労き裂進 展域かを判断することは出来なかった。

疲労試験及び即時破壊試験により破壊した試験片につ いて，き裂の枝分かれまでの距離 $2 l$ と最大負荷応力 $\sigma_{\max }$ との関係を図 10 に示す。疲労破壊した試験片にお いて $\sigma_{\max } \sqrt{l}=c_{1}$ (一定) が, 即時破壊試験により破壊 した試験片について $\sigma_{\mathrm{f}} \sqrt{l}=c_{2}$ (一定) が成り立つこと が分かる.このとき, 疲労破壊した試験片の $2 l$ の值が 低応力レベルで頭打ちになっているのは, 試験片の大き さの効果であると考えられる。モモド1のデータより求 められた $c_{1}, c_{2}$ の平均値はそれぞれ，9.54 $(\mathrm{MPa} \sqrt{m})$, $10.0(\mathrm{MPa} \sqrt{m})$ であって，両者はほぼ一致した。た だし，疲労破壊した試験片についての値は，直線に乗っ 

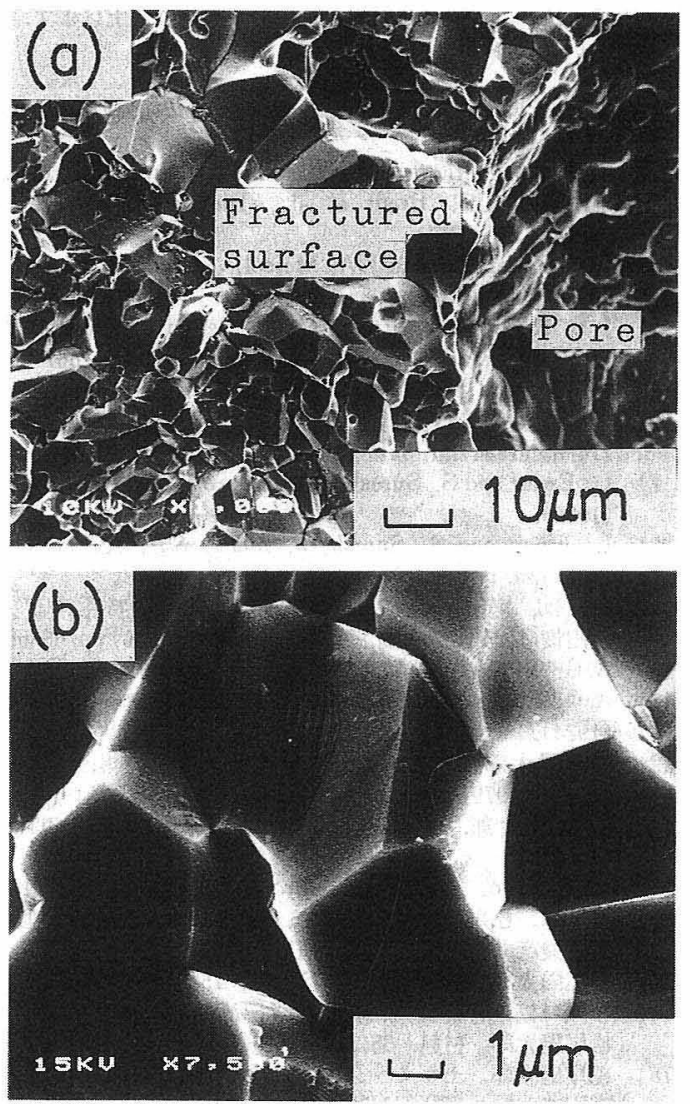

Fig. 9. SEM micrographs of fatigue-fractured surface, which shows intergranular fracture.

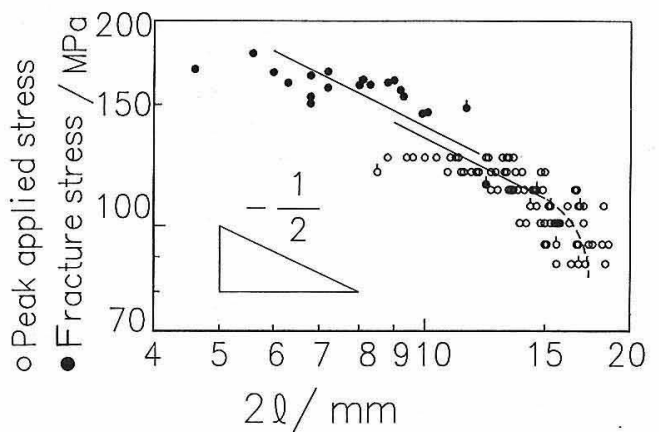

Fig. 10. Relation between applied or fracture stress and crack length until branching in static and fatigue testing; static data, : failed from inside surface (mode 1), : failed from outside surfaces (mode 2); fatigue data, $\bigcirc$ : failed from inside surface (mode 1), $\circlearrowleft$ : failed from outside surface (mode 2 ); the solid lines are calculated from $c_{1}$ or $c_{2}$.

ているデー夕（126〜113 MPa）の平均として求めた. 図中の直線は，これらの值を用いて計算した回帰直線で ある.アルミナについて $\sigma_{\mathrm{f}} \sqrt{c_{\mathrm{b}}}$ の值として, 7.3 $(\mathrm{MPa} \sqrt{m})^{22), 23)}, \sigma_{\mathrm{f}} \sqrt{r_{\mathrm{m}}}$ の值として, ホットプレスし

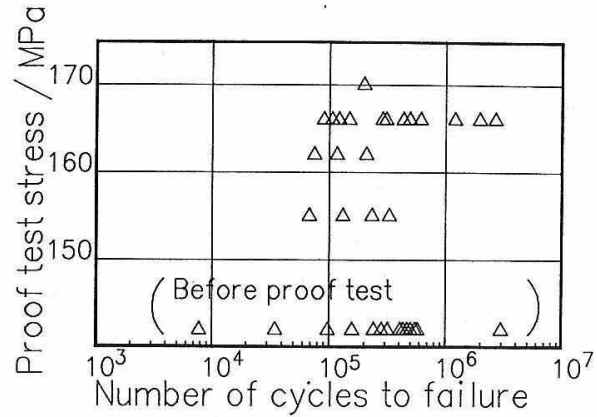

Fig. 11. Fatigue life data of alumina cylinder which passed through proof test.

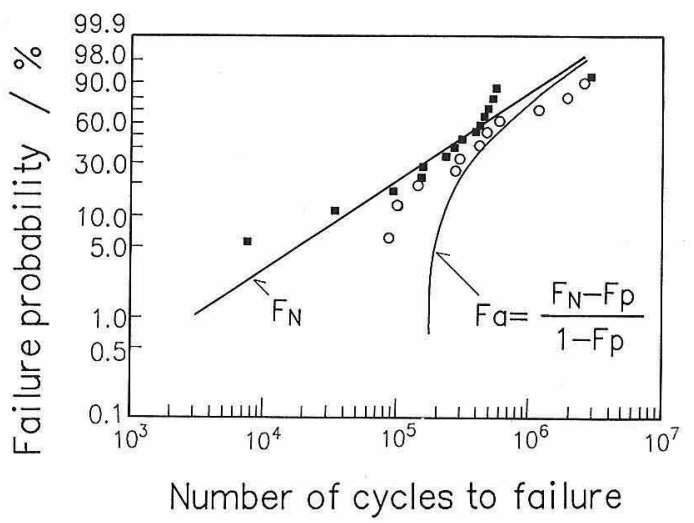

Fig. 12. Weibull plots of number of cycles to failure of alumina cylinder which passed through proof test; proof test stress is $166 \mathrm{MPa} ; \boldsymbol{F}_{\mathrm{p}}=0.32$; : specimens before proof test, $\bigcirc$ : specimens after proof test $\left(\sigma_{\max }=\right.$ $101 \mathrm{MPa})$.

たアルミナについて $10.3 \mathrm{MPa} \sqrt{m}^{27)}$, 純度 $96 \%$ のア ルミナについて $9.1 \mathrm{MPa} \sqrt{m}^{27)}$ が報告されているが, 本実験で得られた值は,これらの值とほぼ一致している.

\section{4 繰り返し疲労寿命に及ぼす保証試験の効果}

保証式験後の試験片のモード 1 の繰り返し疲労寿命を 図 11 に示す。保証試験応力 $166 \mathrm{MPa}$ でのデー夕に 4.2 節と同様な統計解析を行った結果を図 12 に示す.この 図を見て分かるように保証試験を通過した試験片の疲労 寿命は, 繰り返し数 $10^{5}$ 回程度で短寿命側を打ち切られ た形をしており, 繰り返し内圧疲労試験においても保証 試験が有効であることが確かめられた。しかしながら, 実験データは保証試験後に予想される破壊確率,

$$
F_{\mathrm{a}}=\frac{F_{\mathrm{N}}-F_{\mathrm{p}}}{1-F_{\mathrm{p}}}
$$

$\left(F_{\mathrm{p}}\right.$ ：保証試験で破壊する破壊確率, $F_{\mathrm{a}}$ ：保証試 験後の疲労破壊確率, $F_{\mathrm{N}}$ : 全疲学破壊確率)

から計算した曲線よりも短寿命側に位置している. Kamigaito ら ${ }^{28)}$ は保証試験の除荷中の S. C. G. による 
試験片の弱化について考察しているが，この効果及びそ のほかの要因を含めた試験片の疲労寿命の短縮メカニズ ムについて，さらに考察する必要があると考えられる.

\section{5. 総 括}

セラミックスの繰り返し疲労挙動に関して統計論的な 検討を行うために，理論解析及びアルミナ円筒試験片に よる繰り返し内圧疲労試験を行い, 以下の結論を得た.

（1） S.C.G.によるき裂進展のみを仮定し, 不均一 応力場における不活性強度に関する多重モ一ドワイブル 分布と低速き裂進展則を結合して, 繰り返し疲労試験に おける疲労寿命を表す新しい理論式を定式化した。

（2）アルミナ円筒試験片についての即時内圧破壊強 度の分布とその負荷速度依存性を調べ，き裂進展パラ メーター（疲労パラメーター）の推定を行った結果, $n$ $=21, B=16.9 \times 10^{3}\left(\mathrm{MPa}^{2} \cdot \mathrm{s}\right)$ の值を得た。

（3）アルミナ円筒試験片について, 大量の繰り返し 内圧疲労データを得た。明瞭な疲労限の存在は認められ ず, $10^{7}$ 回片振り内圧疲労強度は, 約 $80 \mathrm{MPa}$ 程度で, 即時内圧破壊強度の平均值の約 $50 \%$ 程度であった。ま た，同一応力レベルにおける寿命データのばらつきは $10^{1}$ 〜 $10^{3}$ サイクル程度であった。

（4）アルミナ円筒試験片について得られた大量の疲 労寿命データについて統計解析を行い, 実験結果と (1) で定式化した理論式に基づく推定值との比較を行った結 果，S. C. G. 以外の応力変動によるき裂進展が起こるこ とが推察された。

（5）破面観察よりアルミナ円筒試験片の疲労破壊の 様式は，粒界破壊が支配的であり，き裂の枝分かれまで の長さ $l$ の $1 / 2$ 乗は応力レベル $\sigma_{\max }$ に反比例すること が分かった。このときの $\sigma_{\max } \sqrt{l}$ の值は, 即時破壊にお ける $\sigma_{\mathrm{f}} \sqrt{l}$ の值とほぼ同じ值を示すことが分かった.

（6）アルミナ円筒試験片の疲労寿命に及ぼす保証試 験の効果について調べた結果，保証試験の有効性が認め られる一方で, 最低寿命の推定は保証試験での試験片の 弱化まで含めて考えなければならないことが分かった。

(一部，1988 年 1 月，第 26 回窯業基礎討論会にて発表）

謝辞 アルミナチューブ SSA-S の提供に当たり，日本
化学陶業（株）にご協力頂きました．厚く御礼申し上げます.

$$
\text { 文 献 }
$$

1) A. G. Evans and S. M. Wiederhorn, Int. J. Fract., 10, 379-92 (1974).

2) S. M. Wiederhorn, "Fract. Mech. Ceram.", Vol.2, Ed. by R.C. Bradt et al., Plenum Press (1974) pp. 613-46.

3) J.E. Ritter, Jr. and J.A. Meisel, J. Am. Ceram. Soc., 59, 478-81 (1976).

4) J.E. Ritter, Jr., "Fract. Mech. Ceram.", Vol. 4, Ed. by R. C. Bradt et al., Plenum Press (1978) pp.667-86.

5）松尾陽太郎，材料，33，857-61 (1984).

6）松尾陽太郎, 木村脩七, 安田榮一, 犬飼嵩雄, 窯協, 92, 274-80 (1984).

7) L. Ewart and S. Suresh, J. Mater. Sci. Lett., 5, 774-78 (1986).

8) L. Ewart and S. Suresh, J. Mater. Sci., 22, 1173-92 (1987).

9）例えば, 宮田 昇, “セラミックスの力学的特性評価”, 西田俊彦, 安田榮一編, 日刊工業新聞社 (1986) pp. 66-68。

10) A. G. Evans, J. Mater. Sci., 7, 1137-46 (1972).

11) A. G. Evans and E. R. Fuller, Metal. Trans. , 5, 27-33 (1974).

12）松尾陽太郎，佐藤秀幸，日本機械学会論文集，A-45, 171-78 (1979).

13）松尾陽太郎, 日本機械学会論文集, A-46, 605-12 (1980).

14) Y. Matsuo, Eng. Fract. Mech., 14, 527-38 (1981).

15）例えば，松尾陽太郎，“セラミックスの力学的特性評価”, 西田俊彦, 安田榮一編, 旦刊工業新聞社 (1986) p. 43.

16）松尾陽太郎，村田博隆，材料，33，1545-51 (1984).

17）赤城 協, 神保勝久, 中村 孝, 浦井隆宏, 永井文雄, 松尾陽太郎, 材料, 36, 1005-11 (1987).

18）松尾陽太郎, “セラミックスの力学的特性評価”, 西田俊彦, 安田榮一編, 日刊工業新聞社 (1986) p. 202.

19) W. C. Levengood, J. Appl. Phys, , 29, 820-26 (1958).

20) E. B. Shand, J. Am. Ceram. Soc., 42, 474-77 (1959).

21) M. J. Kerper and T. G. Scuderi, Am. Ceram. Soc. Bull., 43, 622-25 (1964).

22) J. Congleton and N. J. Petch, Phil. Mag., 16, 749-60 (1967)

23) N. J. Petch, "Fracture", Vol.1, Ed. by H. Liebowitz, Academic Press (1968) pp.351-93.

24) D. A. Krohn and D. P. H. Hasselman, J. Am. Ceram. Soc., 55, 208-11 (1972).

25) C.P. Chen and W. J. Knapp, "Fract. Mech. Ceram.", Vol. 2, Ed. by R. C. Bradt et al., Plenum Press (1974) pp. 691-707.

26) F. Guiu, J. Mater. Sci. Lett., 13, 1357-61 (1978).

27) H.P. Kirchner and R. M. Gruver, "Fract. Mech. Ceram.", Vol.1, Ed. by R.C. Bradt et al., Plenum Press (1973) pp. 309-21.

28) O. Kamigaito and N. Kamiya, Yogyo-Kyokai-Shi, 95, 667-71 (1987). 